\title{
5 Procedure-content interaction in attitudes to law and in the value of the rule of law
}

\author{
An empirical and philosophical \\ collaboration
}

\author{
Noam Gur and Jonathan Jackson
}

\subsection{Introduction ${ }^{1}$}

Analytical jurisprudence tends to operate with clean and sharp conceptual distinctions: content-dependence versus content-independence, substance versus form, legitimate versus illegitimate (merely de facto) authority, and so on. This impulse for sharp delineation has important benefits, such as the promotion of precision and clarity, but it also has at least one, less fortunate, side effect: it can, and sometimes does, blind one to certain nuances and complexities of the studied human phenomenon that do not readily fall on one side of the dividing line between alternative conceptual categories.

The empirical input of the social sciences can help the philosopher avoid, or correct for, such oversights. The point made here is not merely that an empirical perspective can serve to remind the philosopher that psychological realities - such as the realities of our attitudes, motivations, and deliberation vis-à-vis the laware not nearly as 'tidy' as the conceptual systems prevailing in analytical jurisprudence. Our point goes further: empirical findings can draw the philosopher's attention to what are, even from the perspective of his or her own discipline, interesting interrelations between the sharply delineated conceptual categories predominating in his or her field of inquiry. It is in this way that empirical inquiry informs philosophical analysis in the present chapter. ${ }^{2}$

Before outlining our argument, an additional comment is worth making regarding the link between empirical and philosophical inquiries. Empirical research can inform a philosophical discussion in various ways, some of which are straightforward (e.g. the verification of factual assumptions, such as assumptions about the human condition or about what people are like, which form part of a chain of moral reasoning), ${ }^{3}$ whereas others are more contested or might even be accused of making an unwarranted leap from descriptive arguments to evaluative conclusions. But one should take care not to invoke the latter accusation too readily; it would often be unjustified, since theorists working at the interface between empirical and philosophical inquiries normally do not suggest 'that we read morality directly off survey results' (to use the words of Alfano, Loeb, \& Plakias 2018, Section 5.2, in a rejoinder to a similar objection). Rather, work 


\section{Noam Gur and Jonathan Jackson}

done in this vein normally draws on empirical resources in more subtle and qualified ways.

At any rate, our own way of proceeding here is not susceptible to the above charge, because we do not treat empirical findings as the proof of a morally evaluative conclusion, but rather as a source of information that, by highlighting certain features of the attitudinal landscape, which may (but need not) have moral-philosophical parallels, draws the philosopher's attention to certain moral possibilities - possibilities that, in turn, ought to be borne out independently by recourse to morally evaluative arguments. To employ once more the words of Alfano, Loeb, \& Plakias (2018, Section 5.2), '[i]magination needs material to work with'. And, insofar as the material, or some aspect of it, is not readily visible from the philosopher's armchair, it is hard to see why he or she should resist the aid of empirical research, so long as it is used in the qualified manner just described.

A brief overview of our arguments is in order before plunging into substantive discussion. We begin, in Section 5.2, with an empirical discussion focused on survey data from the US about law-related attitudes and predictors of legal compliance. The survey, and the completion of this study, preceded the recent anti-police brutality widespread protests sparked by the killing of George Floyd, a development with likely reverberations in terms of public perceptions of police. But our empirical observations, and the principled inferences drawn from them, can be extrapolated to-and, indeed, can be utilised for analysing - these current changes in the landscape of police legitimacy. Consistent with a series of previous studies, we observe that a fair amount of variation in people's ascriptions of legitimacy to the legal system is explained by perceptions of procedural justice in, and lawfulness of, the operation of police and court officials. In addition, we identify two factors as significant predictors of legal compliance (as inferred from self-report): (i) people's belief that they have a (content-independent, moral) duty to obey the law (one index of legitimacy, as defined here); and (ii) people's moral assessments of the content of specific legal requirements (which is often labelled in the literature as 'personal morality', but which we prefer referring to as 'perceived moral content of laws'). Crucially for present purposes, we observe an interactive relationship between these two factors: higher levels of perceived moral content of laws make the felt duty to obey a better predictor of compliance than it otherwise is, and, similarly, perceived moral content of laws is a better predictor of compliance when the felt duty to obey is relatively strong.

Thus, at the empirical level we find that (perceived) procedural justice in, and lawfulness of, police and courts' actions operates as a legitimating factor and predicts compliance; however, the extent to which it predicts compliance is sensitive, at least partly, to people's substantive assessments of the law's content. This empirical picture prompts us, in Section 5.3, to ask the following question, with a particular focus on the moral significance of the rule of law: Might something like the above interactive modality hold good in a parallel, philosophical context, in the sense that procedure-content interaction is not only a feature of people's attitudes towards the law, but also a feature of the moral significance of the rule of law? 
We propose an affirmative answer, locating the value of the rule of law in a hybrid procedural-substantive source. We advance this claim as an alternative to two rival positions in the jurisprudential discourse: the first ('the procedural morality view', as we refer to it) claims that Lon Fuller's eight precepts of legality embody moral qualities not contingent on the law's content; while the second ('the instrumental view', as we call it) claims that Fuller's precepts are merely principles for the efficient execution of the law's substantive goals (whether morally good or bad), and thus have no independent moral value. In contrast, on the view we propound here, Fuller's principles possess (inter alia) an expressive moral quality, but their expressive effect does not materialise in isolation from other, contextual factors - and, in particular, the extent to which it materialises is partly sensitive to the moral quality of the law's content.

It is worth clarifying that we do not present our philosophical and empirical claims as counterparts of one another. Indeed, apart from their distinct characters qua empirical and philosophical claims, there are certain other differences of focus between them (alongside certain parallels) - for example, the notion of 'procedure' is used by each of them with a different emphasis, with one tending to focus on legal process while the other tending to focus on legal form. But such differences do not pose an obstacle for our line of analysis, since we never suggest that our philosophical claim derives, or can be deduced, from the empirical claim. Instead, as was noted above, we merely regard our empirical findings as a source of information or inspiration that leads us to examine a certain philosophical possibility; and we merely point out what we view as an interesting parallel (rather than sameness or equivalence) between our observations in these two contexts.

Having provided a preliminary sketch of our arguments, we now turn to the empirical part of this chapter.

\subsection{An empirical perspective on law-related attitudes: legitimation, legitimacy, and legal compliance}

We begin this section with a brief overview of our two empirical research questions: (1) What legitimates the police and the law generally? (2) Which normative factors predict compliance with the law? Further to this, we comment more specifically on the two corresponding parts of our analysis, and we then detail our method, measures, and results.

\subsubsection{Brief overview}

Our focus here is on people's ascriptions of legitimacy to the legal system (labelled here 'legitimacy'). We follow an approach in the social sciences that measures legitimacy by reference to two connected judgements (Jackson et al. 2012, 2013; Bradford et al. 2014a, 2014c; Hamm et al. 2017; Huq et al. 2017; Gerber \& Jackson 2017; Bradford \& Jackson 2018; Gerber et al. 2018; for a review of the international literature, see Jackson 2018). The first is the perceived 


\section{Noam Gur and Jonathan Jackson}

normative appropriateness of a legal institution: the institution gains legitimacy from a belief that it wields its power in normatively appropriate ways (for discussion of the appropriateness part of the legitimacy construct, see Jackson \& Gau 2015; Jackson \& Bradford 2019). Normative appropriateness is gauged through survey items referring to the extent of alignment between the institution's general operation and people's sense of right and wrong, such as 'Your own feelings about what is right and wrong usually agree with the laws that are enforced by the police and the courts' (we subsume such items under the heading 'normative alignment'). ${ }^{4}$ Positive answers to such questions suggest that the institution is perceived as having a valid claim to exercise power. The second index of legitimacy refers more directly to the perceived authority to govern (which we assume flows from perceived normative appropriateness), and is commonly measured by asking people questions such as whether they are under a duty to obey the requirements of legal institutions, whether they should obey the law even if they disagree with its content, and so on (for discussion of the obligation-to-obey part of the legitimacy construct, see Bottoms \& Tankebe 2012; Tyler \& Jackson 2013; Trinkner 2019; Pósch et al. 2020). As Tyler and Trinkner (2018, p. 3) state:

Perceptions of legitimacy ... lead individuals to feel that it is their obligation to obey rules irrespective of their content. Hence people authorize legal authorities to decide what is correct and then people feel an obligation to adhere to the law. ${ }^{5}$

Drawing on data from a nationally representative US-based survey, we examine the extent to which legal legitimacy is predicted by people's perceptions of how police and court officials behave. ${ }^{6}$ We consider public perceptions of procedural justice (e.g. impartial and accountable decision-making and the quality of interpersonal treatment in dealings with citizens) and lawfulness. We examine the extent to which these perceived attributes explain variation in police legitimacy and, more generally, legal legitimacy (Figure 5.1). Positive associations are taken to mean that procedural justice and lawfulness are two ways in which the police and other legal institutions legitimate themselves in the eyes of the public.

We also assess the predictors of legal compliance (Figure 5.1). In this regard, of particular interest to us is the extent to which the following two factors interact to explain variation in people's compliance with the law: (i) people's belief that they have a (content-independent) duty to obey the law (the second index of legal legitimacy); and (ii) people's moral assessments of the content of specific legal requirements. Testing an interactive relationship between these two factors, we assess whether a felt content-independent duty to obey the law has what might be termed an 'amplifier effect' on the motivational force of the contentdependent belief that specific laws are morally justifiable, and vice versa. In assessing the above two predictors, we adjust for other factors, such as the perceived risk of sanction and expected social disapproval. 


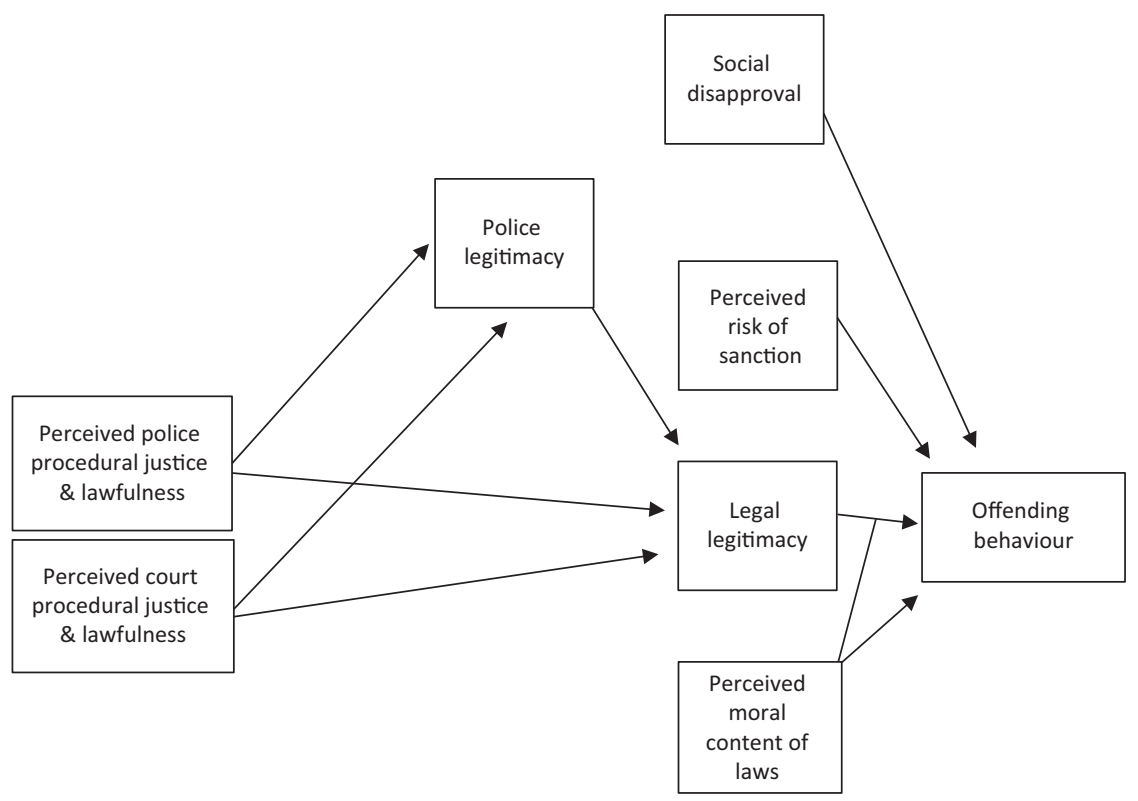

Figure 5.1 Overview of the theoretical model.

\subsubsection{Legitimation: examining the sources of police and legal legitimacy}

Our analysis builds on Trinkner et al.'s (2018) analysis of the same dataset, ${ }^{7}$ which found that police legitimacy was positively predicted by a formative construct based on people's beliefs about officers' actions in terms of interpersonal treatment (e.g. do officers treat citizens with dignity and respect?), decisionmaking (e.g. do officers make unbiased decisions?), and what they call 'bounded authority' (i.e. whether officers respect the limits of their rightful authority). In Trinkner et al.'s analysis, perceptions of appropriate police behaviour predicted police legitimacy, and police legitimacy predicted legal legitimacy more generally. They concluded from this that the police are tangible representations of the law and that interactions with the police provide information not only about police authority, but also about the law and government more generally (Meares 2009; Tyler \& Jackson 2014). On this account, the law's legitimacy is not a given power; rather, it is shaped partly through day-to-day encounters with its agents that serve an educative function in that they facilitate the internalisation of values from which the law gains its legitimacy (Justice \& Meares 2014; Trinkner \& Tyler 2016).

We expand this line of research to include people's perceptions not only of police behaviour but also of how court officials operate, and, as mentioned, we consider in particular perceptions of several primarily procedurally oriented 


\section{Noam Gur and Jonathan Jackson}

qualities as well as lawfulness. Thus, research participants were asked questions such as whether they thought that police and court officials generally make fair and impartial decisions, give people a chance to tell their side of the story, treat people with dignity and respect, make decisions based on the law, and do not arrest people or put them in jail for no reason. We test whether people who believe that officials act in such ways also tend to feel normatively aligned with the police and the law generally and feel a content-independent duty to obey the police and the law generally.

\subsubsection{A mutually amplifying interaction between content-dependent and content-independent factors?}

One method of empirically isolating the law-abiding-and content-independent-motivational force of legal legitimacy involves measuring offending behaviour, estimating its predictors, and focusing on the partial association between offending behaviour and the perceived-authority-to-govern index of legal legitimacy. The statistical modelling used for this purpose controls for the perceived (content-based) moral significance of the acts, the fear of sanction, and the appropriateness index of legal legitimacy. We follow this method here. We build specifically on Trinkner et al.'s (2018) study, which found that duty to obey the law was a significant negative predictor of offending behaviour (e.g. buying goods that might be stolen, shoplifting, and littering illegally), adjusting for normative alignment with the law, the perceived risk of sanction, and the perceived moral significance of the rule's content. ${ }^{8}$ Adjusting for normative alignment with the law in their statistical modelling allowed Trinkner et al. to have greater confidence that the isolated partial association between duty to obey (or, what we referred to as the perceived-authority-to-govern index of legal legitimacy) and legal compliance represents a content-independent motivation to comply.

Now, let us say that:

A is the normative motivation to act/not act in a particular illegal way,

$\mathrm{B}$ is the moral quality one attaches to the particular act (i.e. perceived moral content),

$\mathrm{C}$ is the moral quality one attaches (generically) to abiding by/breaking the law, $\mathrm{B}^{\prime}$ is the amount of motivational force generated by $\mathrm{B}$ alone, and

$\mathrm{C}^{\prime}$ is the amount of motivational force generated by $\mathrm{C}$ alone.

Trinkner et al. (2018) found an additive relationship of $A=B^{\prime}+C^{\prime}$. Thus, for example, the overall normative motivation not to steal (A) equals the sum of the motivational force generated by the (content-dependent) perceived moral wrongness of stealing $\left(\mathrm{B}^{\prime}\right)$ and the motivational force generated by the (contentindependent) felt duty to obey the law $\left(\mathrm{C}^{\prime}\right)$.

Building on Trinkner et al.'s (2018) analysis of their US dataset, we test a novel hypothesis that (content-independent) felt duty to obey the law and perceived moral content of specific laws are not merely additive predictors of compliance, 
but are also interactive predictors of compliance, in the sense that they strengthen each other's link to compliance. Put in the abbreviated form used above, the hypothesis is that $\mathrm{B}$ and $\mathrm{C}$ amplify each other's effect on A. That is, B enhances the motivational force of $\mathrm{C}$, and $\mathrm{C}$ enhances the motivational force of $\mathrm{B}$. For simplified illustration, if we assign the following numerical values, $\mathrm{B}^{\prime}=3$ and $\mathrm{C}^{\prime}=3$, A would be greater than 6 .

\subsubsection{Method}

\section{Sample}

A total of 2,561 respondents were initially drawn from KnowledgePanel, a nationally representative online panel operated by GfK (for more details see Tyler \& Jackson 2014; Tyler et al. 2015; Tyler \& Sevier 2013). The study was described to each individual, an offer of compensation extended, and a reminder email was sent to all people on the list who had not responded after three days. A total of 1,603 individuals completed the survey, representing a response rate of $62.5 \%$. The survey, which was in English or Spanish, was fielded in August and September of 2012 .

\section{Measures}

Because we mostly follow Trinkner et al.'s (2018) approach to conceptualisation and measurement, we direct the reader to that paper for details, while noting below certain differences in the current analysis. Most of the attitudinal measures used a five-point response scale, with higher scores indicating a more positive response to the measured construct.

\section{i) Offending behaviour:}

To assess offending behaviour, respondents were asked how often they had engaged in four different illegal behaviours in the previous five years. The vast majority of respondents reported engaging in no illegal behaviour. We should acknowledge that there is a clear potential for bias with self-report data. Having said that, some comparisons between self-report and other methods have indicated that self-report provides a viable way of establishing frequency of offending action (Hindelang, Hirschi, \& Weis 1981; Thornberry \& Krohn 2000). The four measures of offending behaviour were:

- 'How often in the last five years have you made an exaggerated or false insurance claim?'

- 'How often in the last five years have you bought something you think might be stolen?'

- 'How often in the last five years have you illegally disposed of rubbish or litter?’ 


\section{Noam Gur and Jonathan Jackson}

- 'How often in the last five years have you taken something from a store without paying for it?'

The response categories were 'never' (0), 'once' (1), 'twice' (2), ‘3-4 times' (3), and ' 5 times or more' (4). We took a total count for each research participant. A total of $1,265(82.0 \%)$ had a score of $0,136(8.8 \%)$ had a score of $1,48(3.1 \%)$ had a score of $2,25(1.6 \%)$ had a score of 3 , and $37(2.4 \%)$ had a score of 4 , with a skewed tail due to one person with a score of 16 .

ii) Perceived moral content of laws (aka 'personal morality'):

To measure people's perceptions of the moral quality of each illegal act, we used the following items:

- 'How wrong is it to make an exaggerated or false insurance claim?'

- 'How wrong is it to buy something you think might be stolen?'

- 'How wrong is it to illegally dispose of rubbish or litter?'

- 'How wrong is it to take something from a store without paying for it?'.

The response categories were 'not wrong at all' (1), 'only a little wrong' (2), 'wrong' (3), and 'seriously wrong' (4). We created an index by counting up each research participant's scores. Because of severe skewness of the graph in the range of scores between 6 and 9, and the small number of people in that range, we combined scores from 6 to 9 and created an index from 0 to 6 .

iii) Duty to obey the law:

Responses to the following statements were used to assess the extent to which people consider themselves to be under a duty to obey the law:

- 'People should do what the law says'.

- 'All laws should be strictly obeyed'.

- 'A person who disobeys laws is a danger to others in the community'. ${ }^{10}$

iv) Normative alignment with the law:

Normative alignment with the law was measured using the following indicators:

- 'Your own feelings about what is right and wrong usually agree with the laws that are enforced by the police and the courts'.

- $\quad$ 'The laws in your community are consistent with your own intuitions about what is right and just'.

- 'The laws of our criminal justice system are generally consistent with the views of the people in our community about what is right and wrong'. 
v) Police and courts procedural justice:

Following Trinkner et al. (2018), perceived procedural justice in the operation of the police and courts was measured here through, on the one hand, questions focused on the quality of interpersonal treatment, and, on the other hand, questions focused on the fairness of decision-making. The indicators used regarding police interpersonal treatment were:

- 'How often do the police treat people with dignity and respect?'

- 'How often do the police try to do what is best for the people they are dealing with?’

Similar survey items were used, mutatis mutandis, regarding the interpersonal treatment exhibited by courts (cf. Tyler \& Sevier 2013).

The measures of police fair decision-making were:

- 'How often do the police make fair and impartial decisions in the cases they deal with?'

- 'How often do the police give people a chance to tell their side of the story before they decide what to do?'

- 'How often do the police make decisions based upon the law and not their personal opinions or biases?'

- 'How often do the police explain their decisions and actions in ways that people can understand?'

Similar survey items were used, mutatis mutandis, regarding courts' fair decision-making.

vi) Lawfulness in the operation of police and courts ('police lawfulness' and 'court lawfulness'):

The measures of perceived lawfulness in police behaviour were:

- 'When the police deal with people they almost always behave according to the law'.

- 'The police often arrest people for no good reason' [reverse coded].

The measures of perceived lawfulness in the operation of courts were:

- 'When judges make decisions they almost always behave according to the law'.

- 'How often do courts in your community put people in jail for no good reason?' [reverse coded]. 


\subsubsection{Results}

Relationships among the primary variables of interest are presented in Figure 5.2. ${ }^{11}$ The model should be read as a series of regression paths, representing associations and partial associations between constructs. For example, on the left-hand side there are pathways from four constructs (police lawfulness, police procedural justice, court procedural justice, and court lawfulness) to normative alignment with the police. Here, normative alignment with the police is the response variable (the 'thing being explained') and police lawfulness, police procedural justice, court procedural justice, and court lawfulness are the four potential explanations. As noted below, police lawfulness and police procedural justice emerge as the most significant among the factors explaining variation in normative alignment

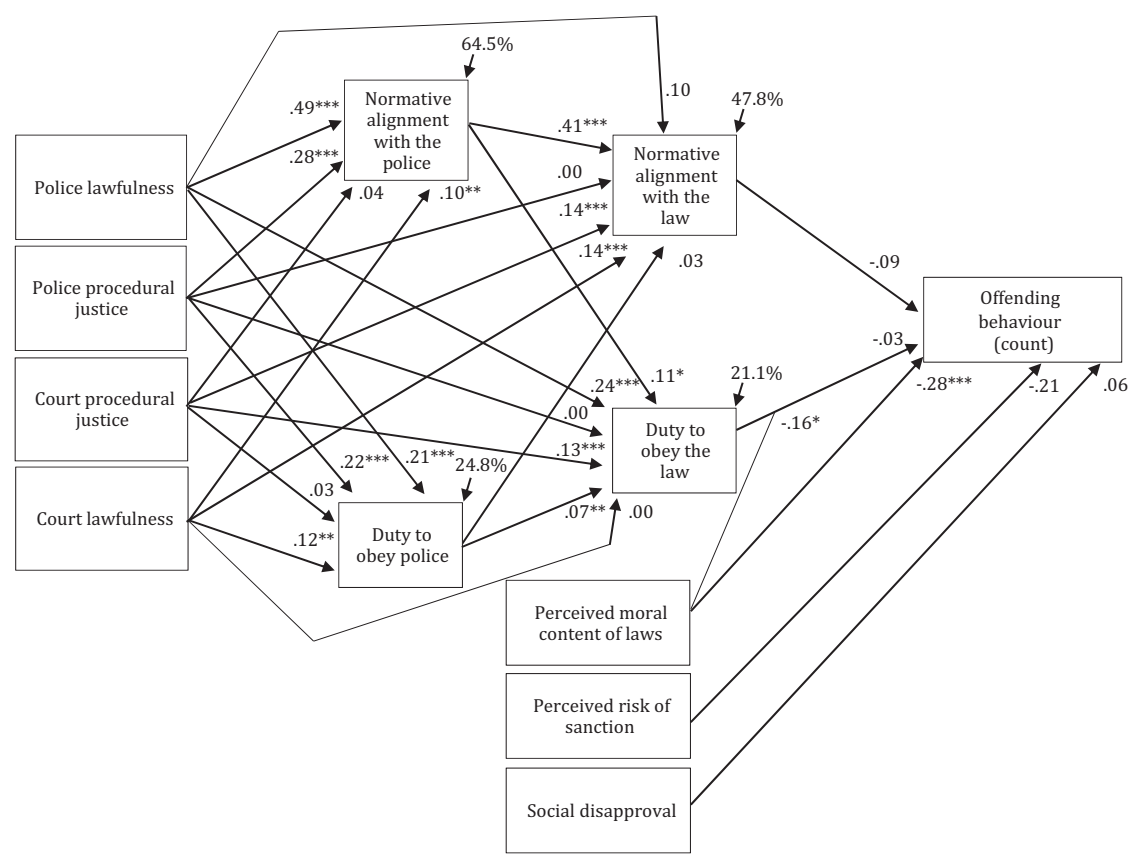

Figure 5.2 A model of procedural justice, police legitimacy, legal legitimacy, and legal compliance, with the interaction between felt duty to obey the law and perceived moral content. Structural equation modelling, predicting, inter alia, a count of offending behaviour (inferred from self-report) using negative binomial regression. Standardised coefficients (STDYX) are given for all but the fitted negative binomial regression part of the analysis (those are unstandardised coefficients). Note: pairs of variables without directed arrows were allowed to correlate. For instance: $r=.13^{* * *}$ normative alignment with the law and duty to obey the law; $r=.29 * * *$ normative alignment with the police and duty to obey the police; $r=.32^{* * *}$ perceived moral content and duty to obey the law; and $r=.08^{*}$ perceived moral content and normative alignment with the law. 
with the police, namely they are the strongest predictors of this response variable. Another thing to note when surveying Figure 5.2 is that standardised coefficients are given for all but the predictors of offending behaviour (unstandardised coefficients are given for offending behaviour because it is a count variable, and a negative binominal regression model is fitted as appropriate to the type of distribution under consideration). So, for instance, the .49 partial regression coefficient for police lawfulness predicting normative alignment with the police should be read as 'a one standard deviation unit increase in police lawfulness is associated with an increase in the expected level of normative alignment with the police of .49 standard deviation units'.

Starting with police legitimacy: just under two-thirds (64.5\%) of the variance in normative alignment with the police is explained, with police lawfulness being the strongest predictor $(B=.49, p<.001)$ and police procedural justice being the second strongest predictor $(B=.28, p<.001)$. When US citizens positively perceive police behaviour as involving lawful action, fair interpersonal interactions with citizens, and fair decision-making, they are more likely to ascribe legitimacy to the institution that officers embody. Additionally, just under one-quarter $(24.8 \%)$ of the variance of duty to obey the police is explained, with police procedural justice being the strongest predictor $(B=.22, p<.001)$ and police lawfulness being the second strongest predictor $(B=.21, p<.001)$.

As regards legal legitimacy, normative alignment with the law $(47.8 \%$ of explained variance) was predicted by normative alignment with the police $(B=$ $.41, p<.001)$, perceived court procedural justice $(B=.14, p<.001)$, and perceived court lawfulness $(B=.14, p<.001)$. Thus, the more US citizens believed that police officers generally act in normatively appropriate ways, the more likely they were to think that the law generally is normatively appropriate. Equally, the more US citizens believed that court officials act in procedurally just and lawful ways, the more likely they were to think that the law is normatively appropriate. Of the variance in felt duty to obey the law, $21.1 \%$ was explained. The main predictor was police lawfulness $(B=.24, p<.001)$, although both aspects of police legitimacy were significant factors (normative alignment, $B=.11, p<.05$; duty to obey, $B=.07, p<.01)$.

Offending behaviour was negatively associated with the interaction between the perceived moral content of laws and the felt duty to obey the law. The partial regression coefficient for the main effect of perceived moral content was $b=$ $-.28, p<.001$, and the partial regression coefficient for the main effect of felt duty to obey the law was $b=-.03, p>.05$. Importantly, the partial regression coefficient for the interaction term between these two factors was $b=-16, p<$ .05 . The parameter estimates indicate that the stronger the felt duty to obey, the stronger the negative statistical association between perceived moral content and compliance with the law. Interactions are symmetrical, so the higher the scores of perceived moral content, the stronger the negative statistical association between the felt duty to obey and compliance with the law.

The range of the perceived moral content index was from 0 to 6 . The range of the duty to obey the law was placed (using principal components analysis) on an index 
1.4

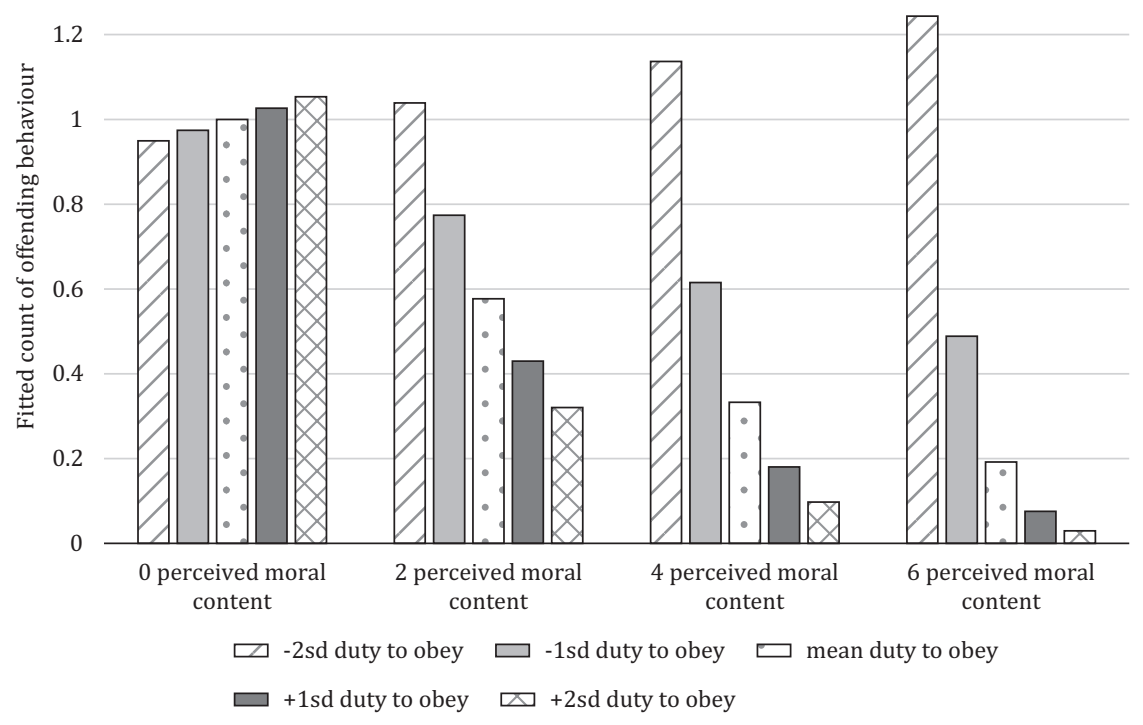

Figure 5.3 Visualising the interactive statistical effects of duty to obey the law and perceived moral content on offending behaviour.

from -3.6 to 1.6 , although hardly anybody had a score below -2 . Figure 5.3 provides fitted counts along the $\mathrm{Y}$-axis and clustered bar charts for scores of perceived moral content of $0,2,4$, and 6 . The five bars in each set represent scores of $-2 \mathrm{sd}$, $-1 s d$, mean $(0),+1 s d$, and $+2 s d$ on the duty to obey index. Note that when the perceived moral content is 0 , there is little difference in the expected counts across the different levels of duty to obey the law. As the perceived moral content increases from 0 to 2,2 to 4 , and 4 to 6 , the negative association between duty to obey and offending behaviour becomes stronger. For instance, if perceived moral content is fixed at the top of the score range (6): when duty to obey is $-2 \mathrm{sd}$, the expected count is just above 1.2; when duty to obey is $-1 \mathrm{sd}$, the expected count is around 0.5 ; when duty to obey is mean $(0)$, the expected count is just below 0.2 ; and so on.

\subsubsection{Empirical conclusions}

Before turning to the philosophical part of this chapter, it is worth summing up our main empirical findings. First, our analysis supports the idea that police legitimacy and, more generally, legal legitimacy are to a significant degree grounded in public perceptions of procedural justice and lawfulness in the operation of police and courts in the US. While our own analysis did not rule out the possibility 
that the arrow of causality goes in the other direction (cf. Nagin \& Telep 2017; Jackson \& Pósch 2019), Trinkner et al. (2019) found in an experimental study that prior perceptions of police legitimacy did not predict judgements of perceived procedural justice.

Second, in prior work (e.g. Tyler 2006a; Jackson et al. 2012; Bradford et al. 2014 b; Trinkner et al. 2018) the perceived moral content of laws was typically found to be the strongest predictor of compliance, while legitimacy was generally also found to be a significant (albeit less strong) positive predictor of compliance, adjusting for perceived moral content. That work has found additive effects of perceived moral content and legitimacy on legal compliance. In comparison, we found a positive statistical interaction between content-dependent values (perceived moral content of laws) and content-independent duty to obey, which means that content-dependent values attached to the required act strengthen (rather than merely add to) the motivational force that a general content-independent duty to obey the law has on people's behaviour (and vice versa). Taking again the example of stealing, people's content-dependent belief that stealing is wrong may form part of their motivation to refrain from stealing, but it may also amplify (rather than just add to) another part of their motivation not to steal, namely that which is generated by their sense that it is wrong to break the law.

\subsection{A philosophical perspective: procedure-content interaction in the value of the rule of law}

In this section, we identify a certain philosophical parallel to the above-observed interactive modality between content and procedure, with a particular focus on the value of the rule of law. Before propounding our ideas, some comments are required on the conception of the rule of law adopted here, its relation to the themes discussed in Section 5.2 above, and the principal controversy surrounding the rule of law's moral significance.

What conception of the rule of law are we assuming for purposes of this analysis? In particular, are we assuming a formal (or procedural) conception of the rule of law, such as Fuller's (1969) and Raz's (2009, pp. 210-218), ${ }^{12}$ according to which rule-of-law requirements pertain only to formal or procedural features of law (e.g. generality, clarity, and prospectivity of legal norms, a hearing by an independent and impartial tribunal, or the like)? Or are we assuming a conception such as Bingham's (2010, p. 67) $)^{13}$ and Dworkin's (1985, pp. 11-12), ${ }^{14}$ which includes also a substantive component in the rule of law, requiring that the content of legal norms conforms to certain standards or values (fundamental human rights, social justice, or the like)?

The conception assumed by our analysis is the formal (or procedural) conception of the rule of law. We adopt such a conception for the following reasons. First, we find merit in some of the objections voiced in the literature against the inclusion of substantive elements in the rule of law-for example, the concern that so doing would render the notion's meaning too open to controversies between differing ideological and political persuasions, thereby eroding the 


\section{Noam Gur and Jonathan Jackson}

notion's distinctive and useful function in theoretical and practical discourse (see expressions of a similar concern in Raz 2009, p. 211; Waldron 2016, Section 5.3). Second, a framework of analysis that lumps form and substance together in one conceptual category, in the way substantive conceptions of the rule of law do, is not likely to best facilitate our primary purpose here, which is to draw attention to a certain relation between form and substance; such a framework of analysis might, even if inadvertently, obscure the distinction between form and substance, and, hence, it might also make it difficult to gain a precise view of their interrelations. Thus, proceeding on a formal conception of the rule of law is likely to be more auspicious for our theoretical purpose. Third, past jurisprudential debate on the moral status of the rule of law, as shaped by dominant contributors such as Lon Fuller (1969), HLA Hart (1965), Nigel Simmonds (2007, 2010), Matthew Kramer (1999, pp. 37-77, 2004), and Kristen Rundle (2012, 2014), among others, has tended to revolve around a formal conception of the rule of law, ${ }^{15}$ and, by way of engaging with past discourse, it would be sensible for us to do the same.

As for the relation between this conception of the rule of law and the themes discussed in Section 5.2 above, it should be noted that there is an overlap between the two, but also that the overlap is merely partial. A clear example of the overlap comes into view when one notes the resemblance between, on the one hand, what Fuller called congruence between officials' actions and declared rules (his eighth principle of legality) and, on the other hand, survey items such as: 'How often do the police make decisions based upon the law and not their personal opinions or biases?'; 'When the police deal with people they almost always behave according to the law'; and '[Do courts] put people in jail for no good reason?'. However, what limits the extent of the overlap and renders it no more than partial is, mainly, the fact that the conception of rule of law assumed here tends to focus on legal form (as defined by Fuller's eight principles of legality), whereas the notions of 'procedural justice' featuring in Section 5.2 tend to focus on legal process. ${ }^{16}$ But, as was indicated earlier, we do not think that such differences undermine our overall line of analysis. This is so not only because the area of overlap noted above is important, albeit limited, but also (and, in fact, primarily) because we do not claim that our philosophical conclusions strictly follow from our empirical conclusions, or that the former are counterparts of the latter. Instead, once more, we merely point out a certain parallel between our observations in these two contexts - that is, a parallel in the modality of interaction between content and procedure/form. This modest claim does not depend for its viability on there being an especially high level of similarity, let alone identity, between the respective contexts of our empirical and philosophical observations.

Reverting to the rule of law, the central contested question among jurisprudential writers in this area can be couched as follows: Do rule-of-law preceptsfor example, generality, clarity, publicity, and prospectivity of legal norms, and congruence between the norms as announced and their actual administrationembody or serve any moral value (or, moral virtue, moral ideal, or the like)? ${ }^{17}$ The literature on this question contains a diverse range of approaches, but for 
present purposes it will be useful to consider two principal positions that have dominated the debate.

\subsubsection{Two conflicting positions on the moral status of the rule of law}

According to the first position, the rule-of-law principles embody a moral virtue not contingent on the law's content. The second position is an antithesis that views the rule-of-law precepts merely as principles for the efficient execution of the law's substantive goals (whether morally good or bad), principles that hold no independent moral value.

The first view is most notably associated with Lon Fuller (1969). To begin with, Fuller approaches his inquiry about law through what can be characterised as a 'purposive' framework of analysis. On this approach, law can be best understood by reflection on its purpose, and, in particular, on the ways it can fail to achieve its purpose and the conditions it must meet in order to achieve it. Famously highlighted by his imaginary tale of the monarch Rex are eight types of failure to craft law in a form fit for its purpose (pp. 33-38). From these eight failures, he derives his eight requirements of legal form: generality; promulgation; non-retroactivity; clarity; non-contradiction; not requiring the impossible; constancy through time; and congruence between official action and declared rules. High level of compliance with these eight precepts represents a form of excellence in legal craftsmanship (pp. 41-42), ${ }^{18}$ whereas, at the lower end of this scale of attainment, these precepts manifest themselves as constitutive elements of law, for a total failure to comply with any one of them results in something that is not a legal system properly so called (p. 39). Most crucially for our purpose, Fuller maintains that these eight formal requirements embody and promote certain moral values. They represent, in his signature terminology, 'the inner' or 'the internal' morality of law- 'inner' or 'internal' because they are integral to the nature of law. This formal or procedural moral aspect is distinguished by Fuller from what he calls 'the external morality' of law (pp. 47 and 96), namely substantive standards of moral behaviour that the law may (or may not) adopt into the content of its rules of conduct. And, in a similar vein, he sometimes describes his eight formal requirements as a 'procedural version of natural law' (pp. 96-97). Drawing on this terminology, we will refer to Fuller's approach as 'the procedural morality view'.

Now, exactly what moral values does Fuller associate with the eight rule-oflaw principles? We can conveniently divide his comments on this into those about direct and those about indirect relations to value. To start with direct relations, he notes, for example, that the last of the eight precepts (i.e. congruence) represents an aspect of reciprocity in the relation between government and citizens regarding the observance of rules, whereby government can be taken to say to the citizen something like: These are the rules we expect you to follow, and if you follow them you have our assurance that we will not sanction you (p. 40). This aspect of reciprocity ties in with a notion of fairness: a government that would sanction a 
citizen without there being any breach of rules on his or her part would be treating that citizen unfairly. In another key remark, Fuller links the eight requirements to respect for human agency and dignity. He notes that 'the view of man implicit in' these eight requirements is that of 'a responsible agent capable of understanding and following rules, and answerable for his defaults' (p. 162), and that every departure from these requirements 'is an affront to man's dignity as a responsible agent' (p. 162). As mentioned above, Fuller draws attention to some further, indirect moral significance of his eight requirements. He notes, for example, that acting by known rules is a precondition for any meaningful appraisal of the justice of the law, both by the public (because minimum consistency, promulgation, clarity, etc., expose actions to public scrutiny (p. 158)) and by the lawmaker herself (because people tend to be more answerable to their own conscience when they have to articulate what they are doing (p. 159)). Thus, in Fuller's view, although the eight requirements are about procedure rather than content, they create conditions conducive to the moral quality of the law's content.

The second, contrasting stance is most prominently reflected in the views of HLA Hart (1965) and Joseph Raz (2009). ${ }^{19}$ Hart accuses Fuller of conflating two different notions: morality and purposive activity (Hart 1965, pp. 1285-1286). Fuller's eight requirements of legal form, claims Hart, are principles for the efficient execution of a purposive activity - and a purposive activity can be morally good or morally bad, depending on the specific purpose pursued. Hart's illustrative example is the activity of poisoning-a purposive activity, whose purpose is to kill another being (p. 1286). Poisoning, Hart points out, also has 'internal' or 'inner' principles: for example, 'Avoid using poisons which cause the victim to vomit' or 'Avoid using poisons if their shape, color, or size is likely to attract notice and alert the intended victim' (p. 1286). But we would not, of course, call these principles of the poisoner's art 'the morality of poisoning'. And this point, Hart maintains, extends to the context of law: since, for him, law can be a vehicle for either morally worthy or morally depraved ends, we should avoid the slip from talking about its inner principles of operation as a purposive practice to talking about its inner morality.

Raz also put forward a number of notable objections to the idea that the rule of law embodies a moral quality. One of his objections builds on, and partly echoes, Hart's argument described in the previous paragraph. Conformity with ruleof-law principles (e.g. promulgation, clarity, prospectivity, and consistency), Raz points out, is essential to law's ability to guide conduct. It has, in other words, an instrumental significance, in that it enables the law to effectively achieve the direct goals it adopts (Raz 2009, pp. 225-226; hence, we will refer to this approach as 'the instrumental view'). But, like many other instruments, it can be utilised for good or ill purposes-namely, the substantive purposes that law is able to secure by effectively guiding conduct can be either morally good or morally bad (depending on the content of the law in question). That is why, according to Raz, the rule of law should not be conceived of as a moral virtue, though it is, in his view, a virtue of law. This last distinction-and, more generally, the notion 
that we can speak of some property as virtuous, but not as morally virtuousseems to comprise Raz's primary supplement to the initial argument of Hart. Raz fleshes out this distinction through a non-legal example: the property of sharpness as it relates to knives. Sharpness is part of what makes a knife effective, but the knife can be used for either morally good purposes (say, to prepare food for a person in need) or for morally ill purposes (say, to murder a person). So, sharpness is not a moral virtue, but we can nonetheless say that a sharp knife is a good knife-which is to say that sharpness is a good-making characteristic of knives. It is a virtue of knives, but not a moral virtue. And, according to Raz, something analogous holds in our context: namely, the rule of law is to law what the sharpness is to a knife-which is to say that the rule of law is a virtue of law, but not a moral virtue ( Raz 2009, p. 226). We should add that, in light of a recent revision by Raz of his view on the rule of law (Raz 2019), we are unsure as to whether he still maintains the above objection; but, since our purpose is not exegetical, this doubt is immaterial to our argument.

\subsubsection{Critical assessment and an alternative proposal: the hybrid view}

We will comment on the two foregoing positions and put forward our own approach. The instrumental view, as explained above, declines to attach moral value to the procedure embodied in the rule of law; the rule of law can at most serve morally valuable substantive goals reflected in the content of certain laws (insofar as this is the case). This, we will argue, is an erroneous position. The procedural morality view, on the other hand, ascribes to rule-of-law procedures moral value, which it views as entirely independent of the content of law. This, too, is erroneous in our view, as will be explained below. How can both these positions be mistaken at once? And if they are, what is the correct position? There is, we suggest, a middle path between these two positions, which better captures the moral significance of the rule of law. This middle path emerges into view with the following, twofold recognition: a given procedural feature of law can have a genuine moral-value-endowing quality (i.e. a genuine capacity to contribute, in itself, to the moral value of law); and yet, at the same time, the materialisation of that moral value - namely, the degree to which, or even whether at all, it materialises-may be partly sensitive to the law's content and substantive ends.

The twofold recognition just stated (which will assume a more concrete form below) reflects a type of hybridity between procedural and substantive moral qualities-hence, we term our proposed view 'the hybrid view'. The possibility of a hybrid modality involving content and procedure initially surfaced (if in a somewhat different form) in the course of our empirical analysis in Section 5.2. It was observed there that, empirically speaking, each of the following factors makes a significant contribution to compliance: (i) content-specific assessments of individual laws, and (ii) ascriptions of legitimacy to the legal system, which are themselves predicted significantly by perceived procedural justice and lawfulness. But 
the analysis also revealed an interactive, and synergetic, dynamic between these two factors, one aspect of this interaction being that higher levels of contentspecific moral approval make legitimacy - and, by implication, make perceived procedural justice and lawfulness - a better predictor of compliance than it otherwise is. ${ }^{20}$ When it comes to people's attitudes towards the law, then, procedural qualities perceived in the application of law operate as a legitimating factor and have a genuine influence on people's actions, but the extent of their influence is sensitive, at least partly, to people's substantive assessments of the law's content. This empirical picture prompts us to ask: Could it be the case that this (or some comparable) type of content-procedure hybridity not only is a feature of people's common attitudes towards law, but also characterises the actual moral significance of some attributes of law? We consider this possibility here with a focus on rule-of-law attributes. So the question can be couched as follows: Is there a philosophical explanation whereby the moral significance of the rule of law is shown to consist, wholly or partly, in content-procedure hybridity? We believe there is such an explanation, and will outline it in the following paragraphs.

The explanation starts with the moral value (or, at any rate, potentiality for moral value) attributable to procedural (or formal) rule-of-law features. In this regard, we believe that, whatever might be said of its deficiencies, Fuller's view contains some true insights. Thus, for example, it seems cogent to say that adherence to the rule of law contributes to the moral quality of the relation between government and citizens by securing a type of reciprocity between them with regard to the observance of rules. ${ }^{21}$ And there seems to be sound (if insufficiently qualified) intuitive sense to the claim that rule-of-law observance expresses-at least at a certain procedural level—respect for human dignity, and that it implicitly envisions the subject as a responsible agent in terms of her engagement with rules and ability to plan her actions in response to them. ${ }^{22}$ So, too, we find a good deal to agree with in subsequent elaborations or restatements of Fuller's position by some of his proponents, such as Simmonds' arguments about the rule of law's contribution to liberty (in the specific sense of independence of the will of another; Simmonds 2007, pp. 99-103 $)^{23}$ and Rundle's elucidation of the relation between legal form and human agency (Rundle 2012, pp. 8-11,97-101). ${ }^{24}$ It is, perhaps, easy to lose sight of the kernel of truth in these positions when dealing with the topic with purely theoretical tools at a relative distance from its practical settings. But even a brief consideration of the practical experience of those at the receiving end of violations of the rule of law should elicit appreciation of the good sense contained in the foregoing views. Consider, for example, the position of a participant in a legally permissible demonstration who is nonetheless detained by the police and held in custody without having violated any previously declared rule (some 'reason' is invoked-say, that he engaged in 'disorderly behaviour' but it is not traceable to any rule). Or, take the case of a shopkeeper who is ordered by the authorities to close her business on account of a failure to comply with regulations that were worded in a language too ambiguous to understand what they actually require. Would these individuals not be correct in thinking 
that the conditions enabling their agency have been prejudiced, and that their liberty (in the sense mentioned above) has been compromised? And, as far as expressive value is concerned, would individuals subjected to such treatment not be right to consider it an expression of disrespect for their agency and autonomy, and to feel an affront to their dignity? An affirmative answer to these questions seems to hold a compelling level of intuitive appeal.

So, why not view the value of the rule of law as dependent purely on procedural (or formal) attributes? What sort of content-procedure interaction do we recognise that leads us, instead, to adopt a hybrid understanding of that value? One principal type of content-procedure interaction revolves around the expressive significance of the rule of law. While adherence to rule-of-law standards is capable and apt to bear the expressive significance highlighted in the previous paragraph, its expressive effect partly depends for its materialisation (or, at least, its full materialisation) on contextual factors; and, as part of this, the degree to which it materialises is sensitive to the moral quality of the law's content. ${ }^{25}$ This claim rests on a recognition that is hardly unique to the specific context of the rule of law. What we observe here, in other words, is a particular case of the general way in which actions derive their expressive significance: they acquire their expressive significance partly by virtue of their own attributes, and from social conventions about their meaning, but their meaning and the message they convey are also sensitive to contextual factors (contextual factors which include, inter alia, other actions originating from the same source). We say more on this in the following section.

\subsubsection{Expressive value, contextual factors, and the rule of law}

To substantiate the above claim, some general comments on the expressive force of actions are required. To start with, it is a conspicuous fact and a salient feature of everyday life that many of our actions, including non-verbal actions, carry expressive significance - that is, they convey meanings (Sunstein 1996, pp. 2021-2022). ${ }^{26}$ Moreover, it seems difficult to adequately capture the richness of our normative and moral lives without accepting that the expressive meaning of an action, in at least some instances, morally matters, and (on the flipside) that whether the action is morally desirable, right, virtuous, or not, may depend (at least in part) on its expressive meaning (in this vein, see, e.g., Pildes \& Anderson 1990; Nozick 1993, pp. 28-32; Anderson \& Pildes 2000; Khaitan 2012, p. 4). It falls outside the scope of this chapter to provide a comprehensive account of the expressive significance of actions. We will thus largely operate within the framework of existing theories and mostly confine our explanatory comments to what is directly material to our claim.

One distinction worth noting at this point is between actions whose entire point is expressive (e.g. gestures such as salutation, tipping one's hat, bowing, shaking someone's hand, or kissing the picture of a loved one) and actions that have other, non-expressive purposes (consisting, e.g., in their physical or 
economic effect) but which also carry expressive meanings (e.g. physically assaulting another with the aim of causing them bodily harm normally also expresses disrespect for their dignity). ${ }^{27}$ In the interest of clarity, it seems warranted to reserve the label 'expressive action' for the former type, and to use a somewhat more inclusive language (e.g. 'expressively significant action') when referring to the latter type or to both types. Now, typically, where actions hold expressive moral significance, what those actions manifest is an attitude-for example, an attitude towards some person or persons, be it contempt, care, compassion, forgiveness, courtesy, or some other kind. But this is not to say that expressive meaning is reducible simply to the actor's (or indeed to any other person's) subjective state of mind (Anderson \& Pildes 2000, pp. 1512-1513, 1574). To give one example, an action can be offensive even when the actor is oblivious to its offensive meaning or positively believes that it conveys some other inoffensive meaning (p. 1524). Although the actor's subjective state of mind is morally relevant, regard must be had to other factors, whether for pragmatic or substantive reasons. Determinations of expressive meaning, as emphasised by several writers, are exercises of interpretation or construction that are at least partly guided or constrained by objective standards (Anderson \& Pildes 2000, pp. 1512, 1525; Khaitan 2012, pp. 9, 11-13). In some instances, such determinations will involve a relatively high measure of changeability according to local conventions and cultural codes - by way of example, subtly acting as if you have not noticed an acquaintance in the street in order not to be held up in a conversation might be socially acceptable in some cultures, but might come across as aloof and unsociable in other cultures. ${ }^{28}$ In other instances, however, it may be warranted for the attribution of expressive meaning to transcend, or break away from, specific social convention in response to less (or non-) contingent considerations. To borrow an example from Anderson and Pildes (2000), even when it was socially acceptable for 'men in business settings to routinely compliment their female colleagues and subordinates on the way they looked', there was nonetheless something insulting in that behaviour, in that it 'amounted to treating women as if they were not serious workers, but merely sexual or aesthetic adornments in a business scene' (pp. 1524-1525).

Especially pertinent to our argument is the following point. As is normally the case with exercises of interpretation, the attribution of expressive meaning to an action is sensitive to the context, and the context may include, inter alia, other actions originating from the same source. Context-sensitivity is a familiar and widely accepted feature of interpretation, certainly when it comes to the interpretation of verbal utterances, and there is no reason, it seems to us, to make an exception in this regard for the interpretation of non-verbal actions. ${ }^{29}$ Moreover, as a concomitant to the preceding point, contextual factors may bear on the attribution of moral significance to both verbal utterances and non-verbal expressive actions. Suppose, for example, a speaker (Jessica) begins a statement with the words 'With all due respect to X ...', but the rest of the statement is, in content and/or style, disrespectful to X. Should this not reflect on the expressive meaning 
and significance we are ready to assign Jessica's words 'With all due respect', perhaps inclining us to construe them as words of irony rather than an actual expression of respect? And should we not say something similar when the case involves, instead of an utterance, an expressive gesture-as, for example, when James shakes hands with George or smiles at him, but all the other actions he performs before and after that gesture are invariably unfriendly to George? It seems highly cogent to think that the full view of James' behaviour towards George detracts from, or undermines, the expressive significance his gesture could otherwise have, or even imbues it with the negative quality of a formal device used to disguise an improper attitude. Or, further consider Mark's actions of holding the door open for his companion or placing a hand on the companion's shoulder during their conversation. Are his actions courteous and friendly, or are they patronising? The answer may be sensitive, inter alia, to whether the general context of their relationship involves actions of domination and superiority, or instead respect between equals. Further examples in this vein, involving expressive or expressively significant actions, can be constructed. ${ }^{30}$

Actions by a legal authority, which are the type of action of interest here, are no exception to the above point: the expressive significance of such actions, or of any given aspect thereof (e.g. their procedure or substance), is also sensitive to context. As Hellman puts it in an article discussing the expressive meaning of government actions through the prism of the Equal Protection Clause, 'understanding their meaning [is] an inherently contextual task' (Hellman 2000, p. 29). And the context, it should be stressed, may include not only its (non-legal) factual backdrop, but also related actions of the same institution or related aspects of its operation. Consider, first, an example illustrating the context-sensitivity of expressive meaning within the law. In the case of County of Allegheny v. ACLU, 492 US 573, 601 (1989), the US Supreme Court considered whether two displays of religious symbols on public property in Pittsburgh amounted to endorsements of religious beliefs in violation of the First Amendment's Establishment Clause. ${ }^{31}$ Justice Blackmun for the court made the following remark on how the test should be applied:

the government's use of religious symbolism is unconstitutional if it has the effect of endorsing religious beliefs, and the effect of the government's use of religious symbolism depends upon its context.

Applying this test, Blackmun ruled that in one of the displays, which set a Hanukkah menorah next to a Christmas tree and a sign saluting liberty, the settings neutralised any message of endorsement of Judaism that might otherwise be conveyed by a menorah, whereas in the second display, where a crèche was displayed alone, the crèche retained its religious meaning.

Contextual factors do not cease to be relevant when the law's expressive significance is analysed from a moral standpoint. Thus, when we consider the 


\section{Noam Gur and Jonathan Jackson}

expressive moral significance of the law's procedural or formal mode of operation, the relevant context may encompass, inter alia, the law's substance or content. Suppose, for example, that your legal system limits its impositions on you to the confines of previously declared rules - a procedural mode of operation that can normally be regarded as an expression of respect for your dignity-but the content of its rules expresses the opposite attitude, disrespect for your dignity, in that it oppresses you or wrongly discriminates against you. ${ }^{32}$ The content of its rules, on our approach, detracts from the message of respect its procedures could otherwise convey - it takes away from its credibility as an expression of a genuine attitude of respect. Indeed, it is not unreasonable to suspect that a government of this sort conforms to the rule of law not out of respect for its citizens, but in order to mask its iniquitous agenda with a mantle of legitimacy, and in this way to lower people's moral guard and avoid civil resistance-a strategy involving a form of manipulation that actually signifies an attitude of disrespect for citizens' autonomy, agency, and dignity. And, in a similar vein, such content-procedure hybridity can manifest itself in positive terms too: namely, when the rule of law is adhered to in a context where government also shows respect for citizens by adopting morally appropriate substantive policies into its laws, the expressive value of rule-of-law adherence, and the relational quality attached to it, are likely to materialise and flourish to their fullest potential.

To forestall possible misunderstanding, note that the hybridity we identify here concerns the value of the rule of law (and the conditions for the materialisation of that value), not the question of what the rule of law is (i.e. which requirements it includes). The latter question was commented on at the outset of Section 5.3, where we adopted for the purpose of this analysis a formal or procedural conception of the rule of law; our proposal does not depart from this presupposed conception.

Finally, how do we perceive the relationship between our argument and relational theory of procedural justice? As we see it, our argument dovetails well with relational theory of procedural justice, even if it is not strictly dependent on it or exclusively bound up with it. A few words of explanation are required. Relational theory of procedural justice (in its normative variety propounded by Meyerson \& Mackenzie 2018) locates the value of procedural justice in 'the message of social inclusion and equality sent by satisfactory interpersonal interactions with authorities' (p. 7), and its positive contribution to individuals' sense of self-respect and self-worth. The evaluative frame of reference used by this approach is focused neither on the community per se nor on a socially atomistic notion of the individual, but rather on the individual as a social creature whose identity is constituted through interpersonal relationships and in the context of the broader social and political environments' in which he or she lives (p. 6).

Now, by way of relating this outlook to our own argument, two aspects of their compatibility should be highlighted. First, like our own argument, the relational conception of procedural justice contains reference to, and (at least implicit) recognition of, the expressive significance of actions. Thus, for instance, the relational conception of procedural justice adverts to the 'message of social 
inclusion and equality sent by satisfactory interpersonal interactions with authorities', noting that satisfactory treatment by group authorities 'symbolically communicates the information that we possess value or status in the eyes of our community' (p. 7, emphases added). Such expressive attributes possibly suggest that the relational conception of procedural justice should even be subsumed as a specific variety of expressive theories of value. Second, a relational outlook seems particularly auspicious for our argument, or at any rate to one crucial element of our line of reasoning - namely, our emphasis on context-sensitivity in the attribution of expressive significance to actions. This is so for the following reason. The very idea of a social or interpersonal relationship implies an enduring connection and association between the relevant parties that extends beyond a mere one-off interaction, and it is plausible that this sort of relational backdrop would also reflect on the expressive significance attached to actions done in a relationship. Thus, especially in the context of a relationship-be it a relationship of friends, spouses, employer-employee, or government-citizen-it seems appropriate to attach expressive significance to various actions not by seeing them in complete isolation from one another, but by taking a more holistic view of the relationship and of certain other actions performed in it. This notion is highly consonant with our claim that the expressive significance of legal procedure or form is sensitive to its context, and to the law's content as part of that context. To couch an example borrowing the terminology of relational theory, 'the message of social inclusion and equality' sent by adherence to due procedures will be, ceteris paribus, considerably attenuated (if not completely obliterated) where the associated laws have, say, racially segregating or gender discriminatory content, rather than just and equitable content. In sum, then, although our line of reasoning has not been developed in terms confined to relational theory, a relational outlook, we believe, strikes a particularly harmonious tone with our argument.

\subsection{Conclusion}

This collaborative work initially put forward a number of empirical claims regarding law-related attitudes and predictors of compliance, which, in turn, inspired a fresh engagement with the legal-philosophical question of the moral status of the rule of law.

Our empirical observations were summarised at the end of Section 5.2. At this point, it suffices to reiterate one key empirical finding regarding the interactive effect between procedural attributes and lawfulness on the one hand and moral content on the other. While we observed that procedural justice and lawfulness perceived in police and courts' operation predict people's compliance (as inferred from self-report), we also found that the strength of their predictive quality is sensitive to people's substantive assessments of the law's content. In particular, higher levels of moral approval of a given rule's content render the (more generic) ascription of legal legitimacy — and, by implication, render perceived procedural justice and lawfulness-a better predictor of compliance than it otherwise is. 


\section{Noam Gur and Jonathan Jackson}

In Section 5.3, we put forward a jurisprudential argument with a certain parallel to the above interactive phenomenon. The specific context of this argument was the debate over the moral value of Fuller's rule-of-law precepts. Fuller's procedural (or formal) precepts, we recognised, have a genuine capacity to carry expressive moral value, but we argued that the realisation of their expressive potential involves (and depends upon) a type of hybridity of procedure (or form) and content. In other words, the expressive effect of these procedural (or formal) requirements does not materialise in isolation from other, contextual factors; and, in particular, the extent to which it materialises is partly sensitive to the moral quality of the law's content. This, we suggested, is a specific case of the general way in which actions derive their expressive significance: they acquire their expressive significance partly by virtue of their own attributes, and from social conventions about their meaning, but their meaning and conveyed message are also sensitive to contextual factors (including other actions originating from the same source). Thus, if certain aspects of government's operation are such that they normally express respect for your dignity (e.g. limiting its impositions on you to a set of previously declared rules), but other related aspects of its operation are such that they clearly express the opposite attitude, namely disrespect for your dignity (e.g. subjecting you to rules whose content oppresses you or wrongly discriminates against you), then the latter contaminate the message of the former, detract from it, or take away from their credibility as expressions of a genuine attitude of respect. And the same idea has a positive facet: when the rule of law is adhered to in a context where government also shows respect for citizens by adopting morally appropriate substantive policies into its laws, the expressive value of ruleof-law adherence is then likely to materialise and flourish to its fullest potential.

\section{Notes}

1 We are grateful to the editors for their valuable comments and suggestions. We also thank Charis Kleio Bagioki and Zinat Jimada for their diligent work as research assistants in connection with this chapter.

2 That jurisprudence can benefit from-or, even, that it is essential for it to draw on-social scientific empirical inquiry is a notion endorsed by a sizable number of theorists (in various distinct versions not necessarily fully identical to our own). See, for example, Roger Cotterrell (2018, Chapter 4); Nicola Lacey (2010); Brian Leiter (2007, 2009); Brian Tamanaha (2000, esp. p. 288); William Twining (2009); Kevin Walton (2015). Regarding Leiter's position, see also the discussion in Dickson (2011).

3 As can be seen, e.g., in Gur (2018, pp. 110-131, 181-192).

4 Wording the measures of perceived normative appropriateness in a general way (as done, e.g., in the above cited survey item) avoids the imposition of specific criteria, thus leaving which specific criteria people use for judging appropriateness an open empirical question (Tyler \& Fagan 2008; European Social Survey 2011; Jackson et al. 2013; Tyler \& Jackson 2014). We follow the same approach here.

5 See Trinkner (2019) for discussion of whether Tyler (2006a, 2006b) specifies duty to obey as downstream to legitimacy or a constituent of legitimacy.

6 For discussion of the distinction between possible sources of legitimacy and constituent components of legitimacy, see Huq et al. (2017); Jackson (2018); Jackson \& Bradford (2019); Trinkner (2019). 
7 With some limited modifications, namely a few survey items from their dataset that are not used, or that are used differently, in our analysis.

8 See also evidence on tax compliance from Murphy et al.'s (2016) Australianbased study.

9 In theory, a negative response to this item might be compatible with a belief in an overridable (or 'prima facie') duty to obey the law. But we still consider that respondents' choice on a five-point scale are, by and large, indicative of the strength of their felt duty to obey (an assumption reinforced by the fact that we found the above three items to be strongly correlated); and, at any rate, positive responses to this item indicate a felt duty to obey.

10 It is worth noting that this item is framed generically (referring to 'laws', not, e.g., to 'some' or 'certain' laws) and unconditionally ('is', not, e.g., 'can be' or 'can be, depending on which law ...'), which means it is indicative of a duty not contingent on the content of any specific given rule. This is also reinforced by the fact that we found the above three items to be strongly correlated.

11 Like Trinkner et al. (2018) we use MPlus to fit a path analysis model (using full information maximum likelihood to deal with missing values). We also treat the constructs as formative, in the sense that the measures constitute the construct. Components scores from principal components analysis for the separate indices (with the exception of police lawfulness and court lawfulness, since they had only two indicators each) were saved using Stata and imported to MPlus.

12 A less univocal example in this regard is Dicey's (1885) notion of the rule of law: his notion seems largely procedural, though certain aspects thereof are interpretable as substantive. See relevant analysis in Craig (1997, pp. 470-474).

13 Other notable former judges who endorsed this conception include Aharon Barak (Barak 2006, p. 55) and Arthur Chaskalson (quoted in Agrast, Botero \& Ponce 2011, p. 9).

14 Cf. Allan (1993, ch. 2, 2001, esp. chs. 2-3). See also the discussion in Craig (1997, pp. 477-479, 481-483).

15 Indeed, a substantive conception might be thought to obviate the question of whether the rule of law embodies or serves any moral value.

16 There are conceptions of the rule of law (e.g. Raz 2009, pp. 214-218; Waldron 2008, pp. 6-9) that include both formal Fullerian attributes and process-related attributes. While there are good reasons to view such conceptions as more complete than Fuller's, as said above contemporary debate over the moral significance of the rule of law has frequently centered on Fuller's legality precepts, and, in the limited context of the present discussion, our focus will be similar.

17 This question, it is worth noting, closely bears on the debate over the so-called separability thesis (i.e. over whether there is a necessary conceptual connection between law and morality, and, if so, what it is); and it also bears on issues such as law's capacity to morally bind and to give reasons for action. Regarding the separability thesis, see: Gardner (2012, pp. 27, 48, 193-194, 221-237); Simmonds (2007, pp. 70-73, 2010, pp. 281-283); Green (2008).

18 Though Fuller also explains that prefect realisation of all of these eight principles is 'not actually a useful target for guiding the impulse toward legality' (Fuller 1969, pp. 4l-46).

19 A similar stance is notably adopted and defended by Matthew Kramer (e.g. Kramer 2004). Also note that, while our reading of Hart and Raz is consistent with the standard interpretation of their position, other interpretations have been put forward. Cf., for example, the interpretation offered by Mark Bennett (2011).

20 An interaction in the opposite direction was also observed: namely, content-specific moral approval is a stronger predictor when legal legitimacy is higher.

21 A claim endorsed by Finnis too (2011, p. 274). See also Murphy's (2005) advocacy of this claim. 
22 See also, in this vein, Waldron (2008, esp. pp. 27-28).

23 To wit, Simmonds (2007, p. 101 ) explains that he refers to 'liberty' not in the sense of how wide one's range of optional actions is, for he acknowledges that rules may restrict that range. Instead, he means 'liberty' in the sense that the limits of that range of actions are, at any given point in time, independent of the present will of another person. The rule of law prohibits the ruler from exercising force outside the scope of rules laid down in advance; thus, what we are allowed or not allowed to do at any given point in time is determined by those rules, and not by the present will, or whim, of the rulers. In this connection, see also Hayek (1943, Chapter VI).

24 See also Gur's (2014) discussion of the above work and Rundle's reply (2014, pp. 139-142, 144-147). On effective agency in Fuller's work, see also Winston (1994).

25 In a valuable article on the rule of law, Coleen Murphy briefly makes at one point a statement that can be understood as consistent with our hybrid view (Murphy 2005 , p. 252).

26 Or, as Taylor (1979) puts it, they manifest something in an embodiment.

27 Cf. Wittgenstein's (1993) distinction between instrumental or effective action on the one hand and ritualistic or expressive action on the other.

28 For another example to a similar effect, see Sunstein (1996, p. 2022). See also related point in Taylor (1979, pp. 79-80).

29 Indeed, it is arguable that the role of context in the interpretation of non-verbal expression is often greater than it is with regard to verbal expression, because non-verbal means of expression are often more ambiguous than verbal ones.

30 In some instances, contextual factors that bear on the expressive significance of an action can be cited either separately from the action or as part of the action, depending on which action description is adopted. Consider, for example, Martin's act of supplying food for the sustenance of a certain group of people. Does the action express care and compassion, and, if so, to what extent? This may depend on further factors, such as whether that group consists of destitute homeless people whom Martin came upon or is, in fact, a group of hostages held by Martin. But such factors can plausibly be included in the action description itself (e.g. 'Martin supplies food for the sustenance of destitute homeless people whom he came upon/hostages held by him'). However, our point in the accompanying body-text paragraph is a general one that holds irrespective of this type of example, not least because (expressively relevant) contextual factors cannot always be incorporated in what is a reasonably intuitive (as opposed to, e.g., an oddly contrived or strained) description of an action. Moreover, the essential point of our position on the expressive value of the rule of law-i.e. how that value is sensitive to both the form and the content of the law-could be defended even if formal and content-related features of the operation of legal authority were to be brought together under one action description. For a general discussion of action individuation, see, e.g., Anscombe (1957, $\$ \$ \$ 6,23-26)$; Davidson (1971); Goldman (1971); Thomson (1971); Gallagher (2020, ch. 1).

31 See relevant discussion in Hellman (2000, esp. pp. 25-26); Anderson \& Pildes (2000, pp. 1545-1551).

32 For some relevant examples in the context of law's expressive function, see van der Burg (2001, Section IV).

\section{References}

Agrast, MD, Botero, JC \& Ponce A 2011, 'The world justice project rule of law index 2011', in The world justice project, Washington, available at: https://worldjustice project.org/sites/default/files/documents/WJP_Rule_of_Law:Index_2011_ Report.pdf 
Alfano, M, Loeb, D \& Plakias, A 2018, 'Experimental moral philosophy', in EN Zalta (ed.), The Stanford encyclopaedia of philosophy, available at: https://plato.stanfo rd.edu/archives/win2018/entries/experimental-moral/

Allan, TRS 1993, Law, liberty and justice: the legal foundations of British constitutionalism, Clarendon Press, Oxford.

Allan, TRS 2001, Constitutional justice: a liberal theory of the rule of law, Oxford University Press, Oxford.

Anderson, ES \& Pildes, RH 2000, 'Expressive theories of law: general restatement', University of Pennsylvania Law Review, vol. 148, no. 5, pp. 1503-1576.

Anscombe, GEM 1957, Intention, Basil Blackwell, Oxford.

Barak, A 2006, The judge in a democracy, Princeton University Press, Princeton.

Bennett, MJ 2011, 'Hart and Raz on the non-instrumental moral value of the rule of law: a reconsideration', Law and Philosophy, vol. 30, no. 5, pp. 603-635.

Bingham, T 2010, The rule of law, Allen Lane, London.

Bottoms, A \& Tankebe, B 2012, 'Beyond procedural justice: a dialogic approach to legitimacy in criminal justice', Journal of Criminal Law and Criminology, vol. 102, no. 1, pp. 119-170.

Bradford, B, Huq, A, Jackson, J \& Roberts, B 2014a, 'What price fairness when security is at stake? Police legitimacy in South Africa', Regulation and Governance, vol. 8, no. 2, pp. 246-268.

Bradford, B, Jackson, J \& Hough, M 2014b, 'Police legitimacy in action: lessons for theory and practice', in M Reisig \& R Kane (eds.), The Oxford handbook of police and policing, Oxford University Press, Oxford, pp. 551-570.

Bradford, B, Murphy, K \& Jackson, J 2014c, 'Officers as mirrors: policing, procedural justice, and the (re)production of social identity', British Journal of Criminology, vol. 54, no. 4, pp. 527-550.

Bradford, B \& Jackson, J 2018, 'Police legitimacy among immigrants in Europe: institutional frames and group position', European Journal of Criminology, vol. 15 , no. 5 , pp. $567-588$.

Cotterrell, R 2018, Sociological jurisprudence: juristic thought and social inquiry, Routledge, Abingdon.

Craig, P 1997, 'Formal and substantive conceptions of the rule of law: an analytical framework', Public Law, vol. 21, pp. 467-487.

Davidson, D 1971, 'Agency', in RW Binkley, RN Bronaugh \& A Marras (eds.), Agent, action and reason, Toronto University Press, Toronto, pp. 3-25. Reprinted in Davidson, D 1980, Essays on actions and events, Oxford University Press, Oxford, pp. 43-61.

Dicey, AV 1885, Introduction to the study of the law of the constitution (1982 edn.), McMillan \& Co, London.

Dickson, J 2011, 'On naturalizing jurisprudence: some comments on Brian Leiter's view of what jurisprudence should become', Law and Philosophy, vol. 30, no. 4, pp. 477-497.

Dworkin, R 1985, A matter of principle, Harvard University Press, Cambridge.

European Social Survey 2011, 'Trust in justice: topline findings from Round 5 of the European Social Survey', ESS Topline Results Series, Issue 1, by Jackson, J, Hough, M, Bradford, B, Pooler, TM, Hohl, K, \& Kuha, J, available at: http://www.euro peansocialsurvey.org/docs/findings/ESS5_toplines_issue_1_trust_in_justice.pdf Finnis, JM 2011, Natural law and natural rights, 2nd edn, Clarendon Press, Oxford. Fuller, LL 1969, The morality of law, 2nd edn, Yale University Press, New Haven. Gallagher, S 2020, Action and interaction, Oxford University Press, Oxford. 
Gardner, J 2012, Law as a leap of Faith, Oxford University Press, Oxford.

Gerber, MM, Gonzalez, R, Carvacho, H, Jimenez-Moya, G, Moray, C \& Jackson, $\mathrm{J} 2018$, 'On the justification of intergroup violence: the roles of procedural justice, police legitimacy and group identity in attitudes towards violence among indigenous people', Psychology of Violence, vol. 8, no. 3, pp. 379-389.

Gerber, MM \& Jackson, J 2017, 'Justifying violence: legitimacy, ideology, and public support for police use of force', Psychology, Crime and Law, vol. 23, no. 1, pp. 79-95.

Goldman, A. 1971, 'Individuation of actions', The Journal of Philosophy, vol. 68, no. 21, pp. 761-774.

Green, L 2008, 'Positivism and the inseparability of law and morals', New York University Law Review, vol. 83, no. 4, pp. 1035-1058.

Gur, N 2014, 'Form and value in law', Jurisprudence, vol. 5, no. 1, pp. 85-95.

Gur, N 2018, Legal directives and practical reasons, Oxford University Press, Oxford.

Hamm, JA, Trinkner, R \& Carr, JD 2017, 'Fair process, trust, and cooperation: moving toward an integrated framework of police legitimacy', Criminal Justice and Behavior, vol. 44, no. 9, pp. 1183-1212.

Hart, HLA 1965, 'Book review: "Fuller, The morality of law"', Harvard Law Review, vol. 78 , no. 6, pp. 1281-1296.

Hayek, FA 1943, The road to serfdom, Routledge, London.

Hellman, D 2000, 'The expressive dimension of equal protection', Minnesota Law Review, vol. 85, no. 1, pp. 1-70.

Hindelang, MJ, Hirschi, T \& Weis, JG 1981, Measuring delinquency, Sage Publications, Beverly Hills.

Huq, A, Jackson, J \& Trinkner, R 2017, 'Legitimating practices: revisiting the predicates of police legitimacy', British Journal of Criminology, vol. 57, no. 5, pp. $1101-1122$.

Jackson, J 2018, 'Norms, normativity and the legitimacy of legal authorities: international perspectives', Annual Review of Law and Social Science, vol. 14, pp. $145-165$.

Jackson, J \& Bradford, B 2019, 'Blurring the distinction between empirical and normative legitimacy? A methodological commentary on "Police legitimacy and citizen cooperation in China"', Asian Journal of Criminology, vol. 14, no. 4, pp. 265-289.

Jackson, J, Bradford, B, Hough, M, Myhill, A, Quinton, P \& Tyler, TR 2012, 'Why do people comply with the law? Legitimacy and the influence of legal institutions', British Journal of Criminology, vol. 52, no. 6, pp. 1051-1071.

Jackson, J, Bradford, B, Stanko, EA \& Hohl, K 2013, Just authority? trust in the police in England and Wales, Routledge, Abingdon.

Jackson, J \& Gau, JM 2015, 'Carving up concepts?: differentiating between trust and legitimacy in public attitudes towards legal authority', in E Shockley et al. (eds.), Interdisciplinary perspectives on trust: towards theoretical and methodological integration, Springer, Cham, Switzerland, pp. 49-69.

Jackson, J \& Pósch, K 2019, 'New directions for research into fairness and legal authority: a focus on causal mechanisms', in EA Lind (ed.), Social psychology and justice (Frontiers of Social Psychology Series), Routledge, New York, pp. 181-212.

Justice, B \& Meares, TL 2014, 'How the criminal justice system educates citizens', Annals of the American Academy of Political and Social Science, vol. 651, no. 1, pp. 159-177, available at: https://doi.org/10.1177/0002716213502929

Khaitan, T 2012, 'Dignity as an expressive norm: neither vacuous nor a panacea', Oxford Journal of Legal Studies, vol. 32, no. 1, pp. 1-19. 
Kramer, MH 1999, In defence of legal positivism: law without trimmings, Oxford University Press, Oxford.

Kramer, MH 2004, 'On the moral status of the rule of law', Cambridge Law Journal, vol. 63 , no. 1, pp. 65-97.

Lacey, N 2010, 'Out of the "witches' cauldron"? Reinterpreting the context and reassessing the significance of the Hart-Fuller debate', in P Cane (ed.), The HartFuller debate in the twenty-first century, Hart Publishing, Oxford, pp. 1-42.

Leiter, B 2007, Naturalizing jurisprudence: essays on American legal realism and naturalism in legal philosophy, Oxford University Press, Oxford.

Leiter, B 2009, 'Naturalizing jurisprudence: three approaches', in J Shook \& P Kurtz (eds.), The future of naturalism, Prometheus Books, Amherst, pp. 197-207.

Meares, TL 2009, 'The legitimacy of police among young African-American men', Marquette Law Review, vol. 92, no. 4, pp. 651-666.

Meyerson, D \& Mackenzie, C 2018, 'Procedural justice and the law', Philosophy Compass, vol. 13, no. 12, el2548, available at: https://doi.org/10.1111/phc3. 12548

Murphy, C 2005, 'Lon Fuller and the moral value of the rule of law', Law and Philosophy, vol. 24, no. 3, pp. 239-262.

Murphy, T, Bradford, B, \& Jackson, J 2016, 'Motivating compliance behavior among offenders: procedural justice or deterrence?', Criminal Justice and Behavior, vol. 43 , no. 1, pp. 102-118.

Nagin, DS \& Telep, CW 2017, 'Procedural justice and legal compliance', Annual Review of Law and Social Science, vol. 13, no. 1, pp. 5-28.

Nozick, R 1993, The nature of rationality, Princeton University Press, Princeton.

Pildes, RH \& Anderson, ES 1990, 'Slinging arrows at democracy: social choice theory, value pluralism, and democratic politics, Columbia Law Review, vol. 90, no. 8, pp. 2121-2214.

Pósch, K, Jackson, J, Bradford, B, \& MacQueen, S 2020, 'Truly free consent? Clarifying the nature of police legitimacy using causal mediation analysis', Journal of Experimental Criminology, available online: https://ssrn.com/abstract=2620274

Raz, J 2009, The authority of law, 2nd edn, Oxford University Press, Oxford.

Raz, J 2019, 'The law's own virtue', Oxford Journal of Legal Studies, vol. 39, no. 1, pp. 1-15.

Rundle, K 2012, Forms liberate: reclaiming the jurisprudence of Lon L Fuller, Hart Publishing, Oxford.

Rundle, K 2014, 'Reply', Jurisprudence, vol. 5, no. 1, pp. 133-160.

Simmonds, NE 2007, Law as a moral idea, Oxford, Oxford University Press.

Simmonds, NE 2010, 'Reply: the nature and virtue of law', Jurisprudence, vol. 1, no. 2, pp. 277-293.

Sunstein, CR 1996, 'On the expressive function of law', University of Pennsylvania Law Review, vol. 144, no. 5, pp. 2021-2054.

Tamanaha, BZ 2000, 'Conceptual analysis, continental social theory, and CLS: a response to Bix, Rubin, and Livingston', Rutgers Law Journal, vol. 32, pp. 281-306.

Taylor, C 1979, 'Action as expression', in C Diamond \& J Teichman (eds.), Intention and intentionality: essays in honour of G.E.M. Anscombe, Harvester Press, Brighton, pp. 73-89.

Thomson, JJ 1971, 'Individuating actions', Journal of Philosophy, vol. 68, no. 21, pp. 774-781. 
Thornberry, TP \& Krohn, MD 2000, 'The self-report method for measuring delinquency and crime', Criminal Justice, vol. 4, no. 1, pp. 33-83.

Trinkner, R 2019, 'Clarifying the contours of the police legitimacy measurement debate: a response to Cao and Graham', Asian Journal of Criminology, vol. 14, pp. 309-335, available at: https://doi.org/10.1007/s11417-019-09300-4

Trinkner, R, Jackson, J \& Tyler, TR 2018, 'Bounded authority: expanding "appropriate" police behavior beyond procedural justice', Law and Human Behavior, vol. 42, no. 3, pp. 280-293.

Trinkner, R, Mays, RD, Cohn, ES, Van Gundy, KT \& Rebellon, CJ 2019, 'Turning the corner on procedural justice theory: exploring reverse causality with an experimental vignette in a longitudinal survey', Journal of Experimental Criminology, vol. 15, no. 4, pp. 661-671.

Trinkner, R \& Tyler, TR 2016, 'Legal socialization: coercion vs. consent in an era of mistrust', Annual Review of Law and Social Science, vol. 12, pp. 417-439.

Twining, T 2009, General jurisprudence: understanding law from a global perspective, Cambridge, Cambridge University Press.

Tyler, TR 2006a, Why people obey the law, 2nd edn, Yale University Press, New Haven.

Tyler, TR 2006b, 'Psychological perspectives on legitimacy and legitimation', Annual Review of Psychology, vol. 57, pp. 375-400.

Tyler, TR \& Fagan, J 2008, 'Legitimacy and cooperation: why do people help the police fight crime in their communities?', Ohio State Journal of Criminal Law, vol. 6, pp. 231-275.

Tyler, TR \& Jackson, J 2013, 'Future challenges in the study of legitimacy and criminal justice', in J Tankebe \& A Liebling (eds.), Legitimacy and criminal justice: an international exploration, Oxford University Press, Oxford, pp. 83-104.

Tyler, TR \& Jackson, J 2014, 'Popular legitimacy and the exercise of legal authority: motivating compliance, cooperation and engagement, Psychology, Public Policy and Law, vol. 20, no. 1, pp. 78-95.

Tyler, TR, Jackson, J \& Mentovich, A 2015, 'On the consequences of being a target of suspicion: potential pitfalls of proactive police contact', Journal of Empirical Legal Studies, vol. 12, no. 4, pp. 602-636.

Tyler, TR \& Sevier, J 2013, 'How do the courts create popular legitimacy?: the role of establishing the truth, punishing justly, and/or acting through lust procedures', Albany Law Review, vol. 77, pp. 1095-1137.

Tyler, TR \& Trinkner, R 2018, Why children follow rules: legal socialization and the development of legitimacy, Oxford University Press, New York.

Waldron, J 2008, 'The concept and the rule of law', Georgia Law Review, vol. 43, pp. 1-61.

van der Burg, W. 2001, 'The expressive and communicative functions of law, especially with regard to moral issues', Law and Philosophy, vol. 20, pp. 31-59.

Waldron, J 2016, 'The rule of law', in EN Zalta (ed.), The Stanford encyclopedia of philosophy, available at: https://plato.stanford.edu/archives/fall2016/entries/ru le-of-law/

Walton, K 2015, 'Legal philosophy and the social sciences: the potential for complementarity', Jurisprudence, vol. 6, no. 2, pp. 231-25l.

Winston, KI 1994, 'Legislators and liberty', Law and Philosophy, vol. 13, no. 3, pp. $389-418$.

Wittgenstein, L 1993, 'Remarks on Frazer's Golden Bough', in J Klagge \& A Nordmann (eds.), Philosophical occasions: 1912-1951, Hackett, Indianapolis, pp. 119-155. 